\title{
Development of Zirconia Nanocomposite Ceramic Tool and Die Material Based on Tribological Design
}

\author{
Chonghai $\mathrm{Xu}^{1,2}$, Mingdong $\mathrm{Yi}^{2}$, Jingjie Zhang ${ }^{1}$, \\ Bin Fang ${ }^{1}$ and Gaofeng Wei ${ }^{1}$ \\ ${ }^{1}$ Shandong Polytechnic University \\ ${ }^{2}$ Shandong University \\ PR China
}

\section{Introduction}

With the development of modern manufacturing technology, die is more and more need in high temperature, high pressure, special working conditions or complex working condition [Liu \& Zhou, 2003]. The requirement in mechanical properties of die material becomes higher and higher. It is necessary to improve the new die material [Kar et al, 2004]. Structure ceramics, because of its high hardness, high temperature mechanical property, wear resistance and corrosion resistance, have been widely used [Basu et al, 2004]. However, lower fracture toughness has limited its wide applications. Moreover, the tribological characteristics also need further study [Hirvonen et al, 2006].

Tetragonal zirconia polycrystal (TZP), with lower sintering temperature and high sintering density, have got wide application in modern die industry because of the excellent mechanical properties and transformation toughening effect[Guicciardi et al, 2006]. However, the low hardness restricts their tribological applications [Zhang et al, 2009; Liu \& Xue, 1996; Yang \& Wei, 2000]. Titanium diboride $\left(\mathrm{TiB}_{2}\right)$ has an excellent hardness and wear resistance but with poor fracture toughness and flexural strength [Baharvandi et al, 2006]. The proper addition of $\mathrm{TiB}_{2}$ can improve the hardness of $\mathrm{ZrO}_{2}$ nano-composite ceramic tool and die material with the other mechanical properties still not being decreased [Basu et al, 2005].

The excellent mechanical properties of TZP ceramics are decided mainly by the transformation toughening [Hirvonen et al, 2006]. Stabilizer materials should be added into the zirconia ceramic to obtain the tetragonal zirconia at room temperature for the achievement of the transformation toughening effect [Gupta et al, 1977]. Yttria is one of the most popularly used stabilizers. The incorporation of $\mathrm{Y}_{2} \mathrm{O}_{3}$ can lower the sintering temperature and enhance the sintering density, so that both mechanical properties and wear resistance can be improved. However, the excessive addition of $\mathrm{Y}_{2} \mathrm{O}_{3}$ will cause the difficulty of the tetragonal zirconia to be transformed into the monocline one, reducing the transformation toughening effect. 
Sintering is also the key process in the preparation of ceramic materials to achieve material with high performance of the composite material with defined raw materials [Hannink et al, 2000]. Nanometer grain which has high surface energy and activity can grow fast and move quickly in the sintering process. Using hot pressing technology can lower the sintering temperature and shorten the holding time. The sintering temperature and the holding time are the key sintering parameters to achieve high performance of nano-composite material [Guicciardi et al, 2006]. Moreover, the sintering parameters play an important role on the improvement of mechanical properties through the increase in the transformation toughening effect [Tu \& Li, 1997].

From the friction and wear problems in the application of the existing ceramic tool and die materials, it is necessary to carry out tribological design during the material research. In the present study, a new nanocomposite ceramic tool and die material was prepared by vacuum hot pressing technique with the application of the tribological design, and the processing techniques, microstructure, mechanical properties and the friction and wear behavior was studied.

\section{Experiments}

$\mathrm{ZrO}_{2}$ stabilized by $5 \mathrm{~mol} \% \mathrm{Y}_{2} \mathrm{O}_{3}\left(5 \mathrm{Y}-\mathrm{ZrO}_{2}\right), \mathrm{TiB}_{2}$ and $\mathrm{Al}_{2} \mathrm{O}_{3}$ are the main raw materials with the average particle size of $40 \mathrm{~nm}, 1.5 \mu \mathrm{m}$ and $1.5 \mu \mathrm{m}$, respectively. Both $5 \mathrm{Y}-\mathrm{ZrO}_{2}$ and $\mathrm{TiB}_{2}$ are all commercial powders. The $\mathrm{Al}_{2} \mathrm{O}_{3}$ powders were obtained by roasting the analytically pure $\mathrm{Al}(\mathrm{OH})_{3}$ powders. Before the experiment, $\mathrm{TiB}_{2}$ and $\mathrm{Al}_{2} \mathrm{O}_{3}$ powders were ball milled for 100 hours.

As shown in Fig. 1(a), the particle size of commercial $\mathrm{TiB}_{2}$ powder is about $10 \mu \mathrm{m}$, while that after ball milling is only about $1.5 \mu \mathrm{m}$ (Fig. 1(b)).

Fig. 2 and Fig. 3 are the results of $\mathrm{X}$-ray energy dispersive analysis and particle size analysis, respectively. As shown in Fig. 2, the $\mathrm{Al}_{2} \mathrm{O}_{3}$ powders have nothing impurities. The average particle size of $\mathrm{Al}_{2} \mathrm{O}_{3}$ is about $1.5 \mu \mathrm{m}$ (Fig. 3).

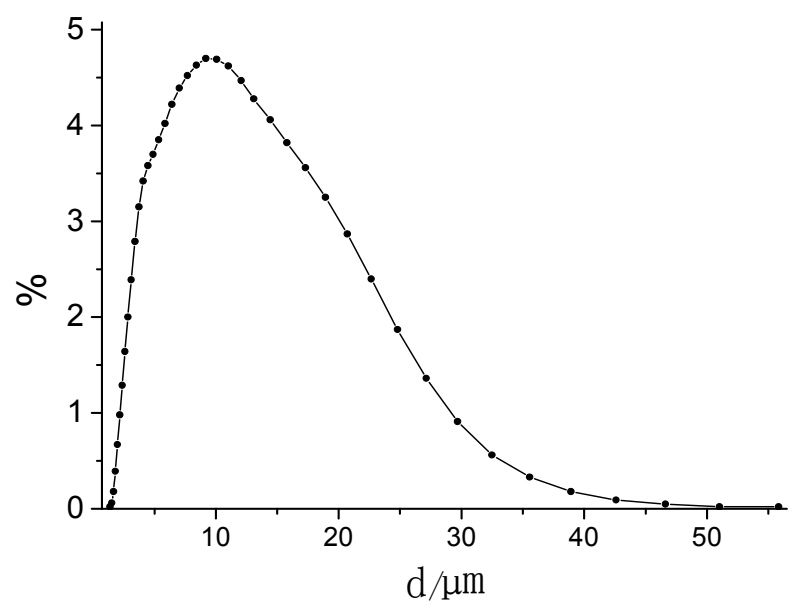

(a) commercial powders 


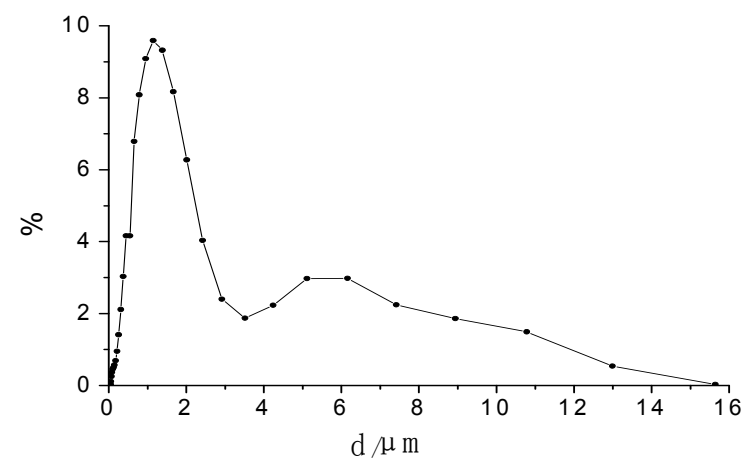

(b) after ball milling

Fig. 1. Particle size distributions of $\mathrm{TiB}_{2}$ powder

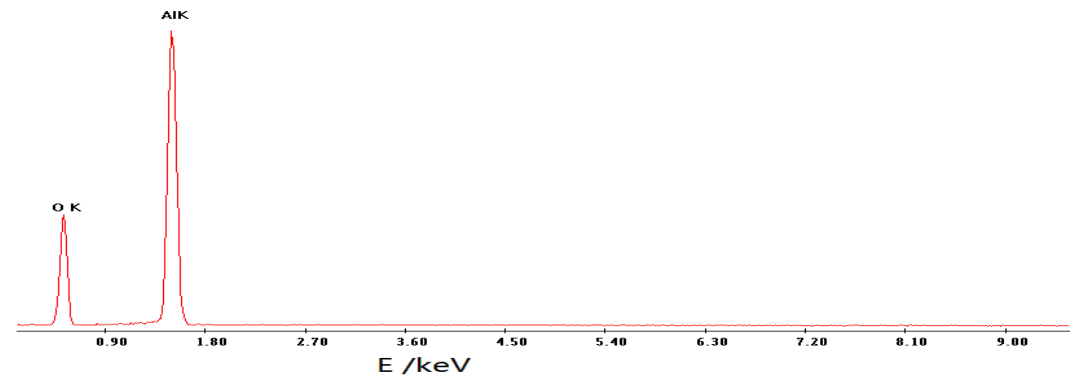

Fig. 2. EDAX of roasted $\mathrm{Al}_{2} \mathrm{O}_{3}$ powder

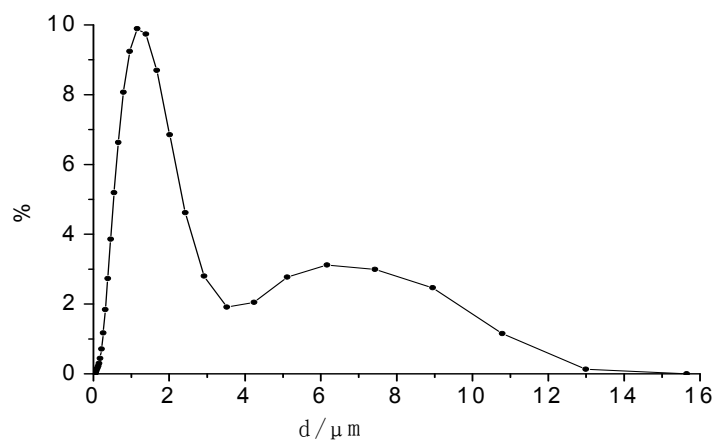

Fig. 3. Particle size distributions of $\mathrm{Al}_{2} \mathrm{O}_{3}$ powder

In the $\mathrm{ZrO}_{2}-\mathrm{TiB}_{2}-\mathrm{Al}_{2} \mathrm{O}_{3}$ nano composite ceramic tool and die material system, $\mathrm{Al}_{2} \mathrm{O}_{3}$ as the reinforcement phase in $\mathrm{ZrO}_{2}$ ceramic, chemical reaction does not occur. But under the high temperature, $\mathrm{TiO}_{2}$ may be formed by the direct reaction between $\mathrm{TiB}_{2}$ and $\mathrm{ZrO}_{2}$ or $\mathrm{Al}_{2} \mathrm{O}_{3}$ which is bad to the mechanical properties. The possible reactions are as follows:

$$
\mathrm{TiB}_{2}+\mathrm{ZrO}_{2}=\mathrm{ZrB}_{2}+\mathrm{TiO}_{2}
$$




$$
2 \mathrm{TiB}_{2}+\mathrm{Al}_{2} \mathrm{O}_{3}=2 \mathrm{AlB}_{2}+\mathrm{TiO}+\mathrm{TiO}_{2}
$$

Using the data in the handbook of thermodynamic data of inorganic compounds, the standard reaction Gibbs free energy of reaction (1) and (2) at $1900 \mathrm{~K}$ are $142.91 \mathrm{KJ} / \mathrm{mol}$ and $697.97 \mathrm{KJ} / \mathrm{mol}$, respectively. Based on the minimum free enthalpy principle, the two reactions do not occur at $1900 \mathrm{~K}$. The result shows that the $\mathrm{ZrO}_{2}-\mathrm{TiB}_{2}-\mathrm{Al}_{2} \mathrm{O}_{3}$ nano composite ceramic tool and die material has good chemical compatibility. Fig. 4 shows the $X$ ray diffraction before and after sintering composites.

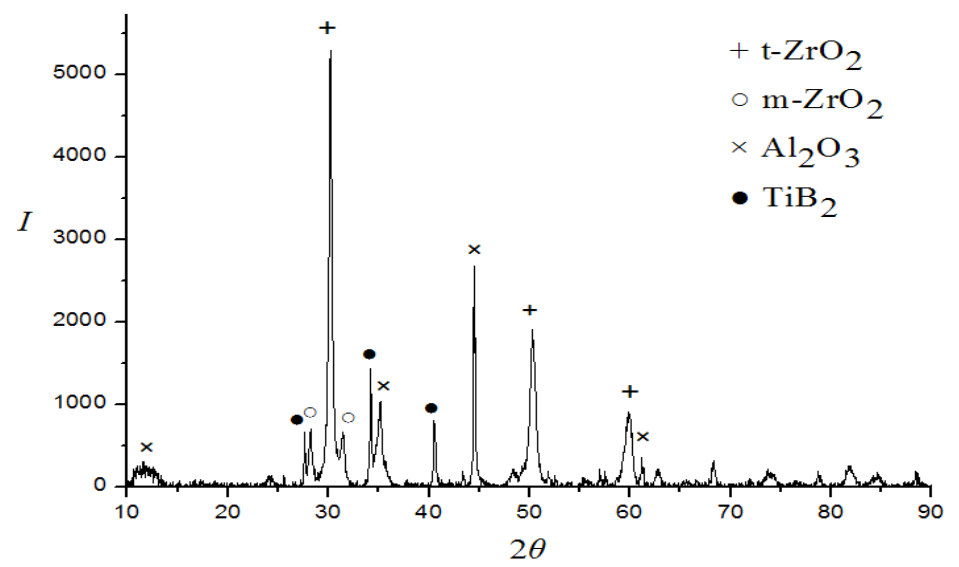

(a) before sintering

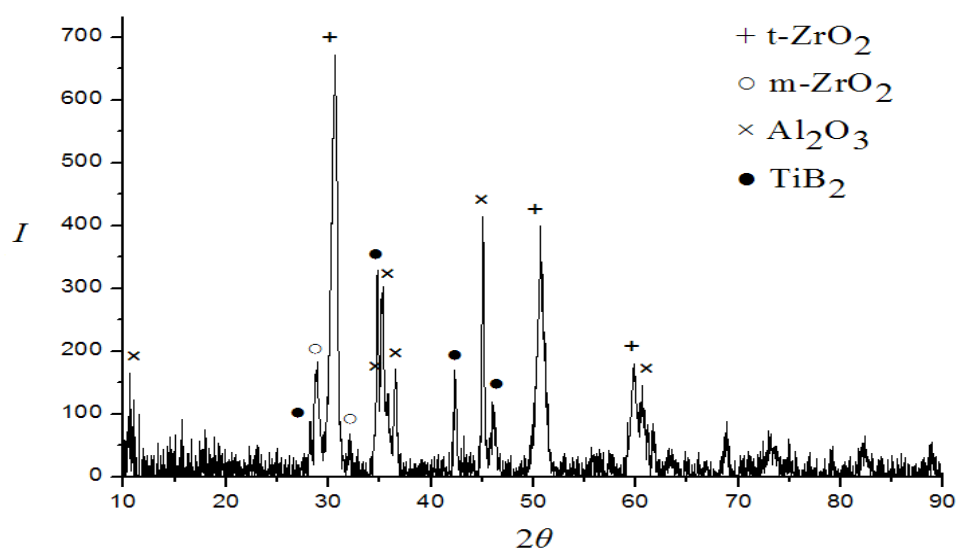

(b) after sintering

Fig. 4. XRD of the ceramic composites

As shown in Fig. 4, the phase of material had not obviously change before and after sintering. It proved that the composites have good chemical compatibility.

$\mathrm{ZrO}_{2}, \mathrm{TiB}_{2}$ and $\mathrm{Al}_{2} \mathrm{O}_{3}$ were mixed together for $48 \mathrm{~h}$ by milling using cemented carbide balls. After milling, the slurry was dried in vacuum and screened. The mixture was hot pressed in 
a graphite mold at $1430^{\circ} \mathrm{C}$ in vacuum with the time duration of $60 \mathrm{~min}$ and pressure of $35 \mathrm{MPa}$. Composite material was made into $4 \mathrm{~mm} \times 3 \mathrm{~mm} \times 36 \mathrm{~mm}$ standard sample after cutting and polishing. The flexural strength was measured by three-point bending method with a span of $20 \mathrm{~mm}$ and loading rate of $0.5 \mathrm{~mm} / \mathrm{min}$. The hardness was measured by Hv120 Vickers hardness tester under the load of $196 \mathrm{~N}$ for $15 \mathrm{~s}$. Fracture toughness was measured by the indentation method. The microstructure and phase of the composite were analyzed with environmental scanning electron microscope (ESEM, model FEI-quanta 200) and X-ray diffraction (XRD, model BRUKER D8).

The wear test was carried on the MMW-1A configuration control multi-purpose friction abrasion tester, using pin on disc form. For the actual operating conditions, 45\# chilled steel rings were selected as the friction pair material. The outer diameter and the inside diameter is $\varnothing 54 \mathrm{~mm}$ and $\varnothing 38 \mathrm{~mm}$, respectively with $10 \mathrm{~mm}$ high. The hardness of the workpiese material is $44 \sim 46 \mathrm{HRC}$ with the surface roughness $\mathrm{Ra}=0.4 \mu \mathrm{m}$.

According to the request of wear tester, material was made into $10 \mathrm{~mm} \times 10 \mathrm{~mm} \times 15 \mathrm{~mm}$ standard sample after cutting and polishing, and the opposite surface $(10 \mathrm{~mm} \times 10 \mathrm{~mm}$ surface) which do the friction attrition experiment was polished to the surface roughness $\mathrm{Ra}=0.1 \mu \mathrm{m}$. After polishing, the sample is dipped into acetone and cleaned with ultrasonic washer for $5 \mathrm{~min}$. Finally, it is dried in vacuum for $24 \mathrm{~h}$.

In the experiment, the sliding dry friction was carried out without any lubricant. The normal load was $160 \mathrm{~N}$ and the rotational speed was $200 \mathrm{r} / \mathrm{min}$. Under this condition, dry friction wear tests of the $\mathrm{ZrO}_{2}$ nano-composites have been carried out. The friction coefficient can be obtained by directly reading in the experiment process. The data were read at $5 \mathrm{~min}$ after the friction starts and a measured value was taken at intervals of $10 \mathrm{~min}$. A total of five measurements were taken to calculate the average as the final result. The wear rate was calculated by expression. The friction and wear appearance of the briquette polishing scratches surface was carried on FEI-quanta 200 environmental scanning electron microscope (ESEM).

\section{Preparation of $\mathrm{ZrO}_{2}-\mathrm{TiB}_{2}-\mathrm{Al}_{2} \mathrm{O}_{3}$ nano composite ceramic too and die material}

\subsection{Components and mechanical property of ceramic material}

In order to improve the comprehensive mechanical properties of $\mathrm{ZrO}_{2}$ ceramic material, the influence of different particle size and contents of $\mathrm{TiB}_{2}$ and $\mathrm{Al}_{2} \mathrm{O}_{3}$ powders on the microstructure and mechanical properties of $\mathrm{ZrO}_{2}$ nano composite ceramic tool and die material is investigated. $\mathrm{ZrO}_{2}$ nano composite ceramic tool and die material is prepared with Vacuum hot pressing technique at $1450^{\circ} \mathrm{C}$ for $60 \mathrm{~min}$ at $30 \mathrm{MPa}$. The results were shown in the Table 1.

As shown in Table 1, the fracture toughness of the composite is good, but the flexural strength and hardness is low. The flexural strength, the fracture toughness and the hardness of the ceramic material reaches $619 \mathrm{MPa}, 12.2 \mathrm{MPam}^{1 / 2}$ and $10.71 \mathrm{GPa}$, and the composites with 10 vol. $\% \mathrm{Al}_{2} \mathrm{O}_{3}$ and 10 vol. $\% \mathrm{TiB}_{2}$ has the optimum comprehensive mechanical property. 


\begin{tabular}{|c|c|c|c|}
\hline Materials & $\begin{array}{c}\text { Fracture toughness } \\
/ \mathrm{MPa} \cdot \mathrm{m}^{1 / 2}\end{array}$ & Hardness /GPa & Flexural strength/MPa \\
\hline $\mathrm{ZB}(5) \mathrm{A}(5)$ & 9.76 & 10.03 & 619 \\
\hline $\mathrm{ZB}(5) \mathrm{A}(10)$ & 10.59 & 10.20 & 501 \\
\hline $\mathrm{ZB}(5) \mathrm{A}(15)$ & 9.95 & 10.36 & 509 \\
\hline $\mathrm{ZB}(10) \mathrm{A}(5)$ & 10.51 & 10.37 & 617 \\
\hline $\mathrm{ZB}(10) \mathrm{A}(10)$ & 11.37 & 10.71 & 612 \\
\hline $\mathrm{ZB}(10) \mathrm{A}(15)$ & 12.20 & 10.19 & 565 \\
\hline $\mathrm{ZB}(15) \mathrm{A}(5)$ & 7.86 & 9.82 & 513 \\
\hline $\mathrm{ZB}(15) \mathrm{A}(10)$ & 7.91 & 10.22 & 524 \\
\hline $\mathrm{ZB}(15) \mathrm{A}(15)$ & 8.11 & 10.14 & 520 \\
\hline
\end{tabular}

Table 1. Mechanical properties of the ceramic tool and die materials

Table 2 shows the mechanical properties of $\mathrm{ZrO}_{2}$ nano composite ceramic tool and die material with different sized $\mathrm{Al}_{2} \mathrm{O}_{3}$ powders. The flexural strength and hardness of the composites with micrometer sized $\mathrm{Al}_{2} \mathrm{O}_{3}$ powders is higher than that with nanometer sized $\mathrm{Al}_{2} \mathrm{O}_{3}$ powders, but the fracture toughness is lower than the latter. In $\mathrm{ZrO}_{2}$ nano composite ceramic tool and die material, $\mathrm{ZrO}_{2}$ transformation toughening effect is the main toughening mechanism, the effect of $\mathrm{Al}_{2} \mathrm{O}_{3}$ on mechanical property is due to the particle reinforcement [Elshazly et al, 2008]. Nanometer sized $\mathrm{Al}_{2} \mathrm{O}_{3}$ has pinning effect on the grain boundary, restrictions the grain boundary sliding, this is propitious to make the matrix grain finer and is good for the fracture toughness. The grain size of the composite with micrometer sized $\mathrm{Al}_{2} \mathrm{O}_{3}$ is bigger than that with nanometer sized $\mathrm{Al}_{2} \mathrm{O}_{3}$, but the effect of particle reinforcement is higher than the latter, this is the main reason of the higher flexural strength.

\begin{tabular}{|c|c|c|c|}
\hline Material & $\begin{array}{c}\text { Flexural strength } \\
/ \mathrm{MPa}\end{array}$ & $\begin{array}{c}\text { Fracture toughness } \\
/ \mathrm{MPa} \cdot \mathrm{m}^{1 / 2}\end{array}$ & $\begin{array}{c}\text { Hardness } \\
/ \mathrm{GPa}\end{array}$ \\
\hline With micro- $\mathrm{Al}_{2} \mathrm{O}_{3}$ & 743 & 7.75 & 11.6 \\
\hline With nano- $\mathrm{Al}_{2} \mathrm{O}_{3}$ & 612 & 11.37 & 10.71 \\
\hline
\end{tabular}

Table 2. Mechanical properties of the ceramic with different sized $\mathrm{Al}_{2} \mathrm{O}_{3}$ powders

Fig.5 shows the SEM morphology of $\mathrm{ZrO}_{2}$ nano composite ceramic tool and die material with different sized $\mathrm{Al}_{2} \mathrm{O}_{3}$ powders. The microstructure of the composite with nanometer sized $\mathrm{Al}_{2} \mathrm{O}_{3}$ powders is finer than that with micrometer sized $\mathrm{Al}_{2} \mathrm{O}_{3}$ powders.

The results showed that the highest flexural strength of $\mathrm{ZrO}_{2}-\mathrm{TiB}_{2}-\mathrm{Al}_{2} \mathrm{O}_{3}$ nano-composite ceramic tool and die material reaches $743 \mathrm{MPa}$ with 10 vol. $\% \mathrm{Al}_{2} \mathrm{O}_{3}$ micrometer sized powders. The fracture toughness increased obviously along with the increase of $\mathrm{Al}_{2} \mathrm{O}_{3}$ nanometer sized powders, and reaches $11.37 \mathrm{MPa} \mathrm{m}^{1 / 2}$. Vickers hardness did not change obviously with different $\mathrm{Al}_{2} \mathrm{O}_{3}$ powders, while it greatly increased with the increases of $\mathrm{Al}_{2} \mathrm{O}_{3}$ content. 


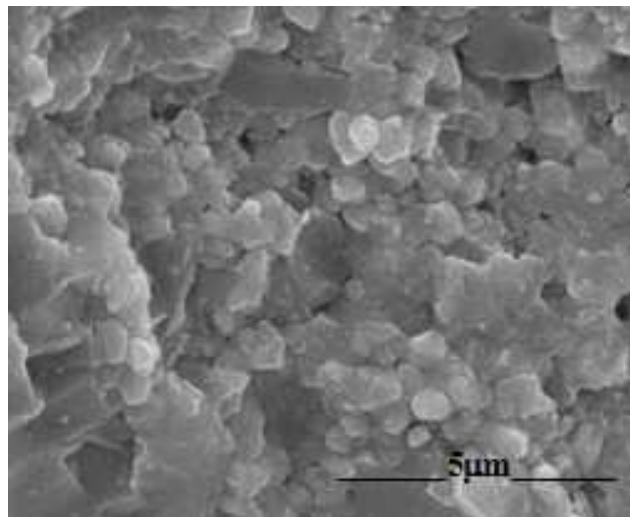

(a) with micrometer sized $\mathrm{Al}_{2} \mathrm{O}_{3}$ powder

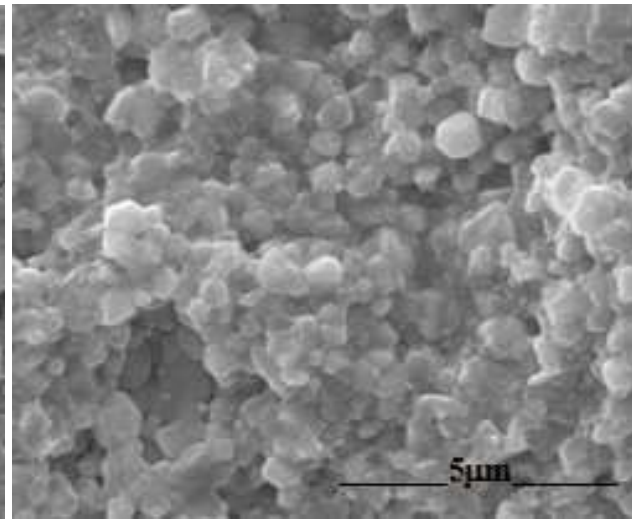

(b) with nanometer sized $\mathrm{Al}_{2} \mathrm{O}_{3}$ powders

Fig. 5. SEM of the composites with different sized $\mathrm{Al}_{2} \mathrm{O}_{3}$ powders

\subsection{Hot pressing technology of ceramic material}

\subsubsection{Effects of holding time}

Fig. 6 shows the effect of holding time on the flexural strength of $\mathrm{ZrO}_{2}$ nano-composite ceramic tool and die material when sintered at $1450{ }^{\circ} \mathrm{C}$. It can be seen from Fig. 6 that the flexural increases first and then decreases with the increase of holding time, reaching the maximum of $878 \mathrm{MPa}$ when the holding time is $60 \mathrm{~min}$. Fig. 7 shows the effect of holding time on the fracture toughness and hardness of the composite material. The hardness increases with the increase of the holding time, reaching the maximum of $13.48 \mathrm{GPa}$ when the holding time is $80 \mathrm{~min}$. Fracture toughness increases and then decreases with holding time increases, reaching the maximum of $9.91 \mathrm{MPa} \cdot \mathrm{m}^{1 / 2}$ when the holding time is $40 \mathrm{~min}$.

Fig. 8 shows the SEM morphologies of $\mathrm{ZrO}_{2}$ nano-composite ceramic tool and die material with the holding time of $20 \mathrm{~min}, 60 \mathrm{~min}$ and $80 \mathrm{~min}$. It can be seen from Fig. 8, the microstructure of the composite material has changed greatly with the holding time increases, and to be the best when the holding time is $60 \mathrm{~min}$. The reason is that proper holding time can improve the microstructure, ceramic material becomes further densification when the holding time is $60 \mathrm{~min}$, and many nano-meter sized grains has found in the grain boundary which contribute to the trans/inter-granular mixed fracture mode occurs.

As a result, the flexural strength and fracture toughness of the composite material when the holding time is $60 \mathrm{~min}$ are better than the other holding time.

Fig. 9 shows the effects of hot pressing temperature on the flexural strength of $\mathrm{ZrO}_{2}$ nanocomposite ceramic tool and die material with the holding time of $60 \mathrm{~min}$. The flexural strength first increases and then decreases with the increase of hot pressing temperature from $1420{ }^{\circ} \mathrm{C}$ to $1470{ }^{\circ} \mathrm{C}$, and reaching the maximum of $1055 \mathrm{MPa}$ at $1430{ }^{\circ} \mathrm{C}$. Fig. 10 shows the effects of hot pressing temperature on the fracture toughness and hardness. As shown in Fig. 10, the change of the hardness and the fracture toughness are nearly the same in trend 
as that of the flexural strength, the hardness reaching the maximum of $13.78 \mathrm{GPa}$ when the hot pressing temperature of $1460{ }^{\circ} \mathrm{C}$ and the fracture toughness reaching the maximum of 10.57 $\mathrm{MPa} \cdot \mathrm{m}^{1 / 2}$ when the hot pressing temperature is $1430^{\circ} \mathrm{C}$. It can be seen that the effect of sintering temperature on the mechanical properties of the composite material is obvious, proper hot pressing temperature can improve the mechanical properties, the flexural strength and the fracture toughness respectively reaching the maximum of $1055 \mathrm{MPa}$ and 10.57 $\mathrm{MPa} \mathrm{m}^{1 / 2}$ at $1430{ }^{\circ} \mathrm{C}$ and the hardness of this sintering temperature is lower than the maximum.

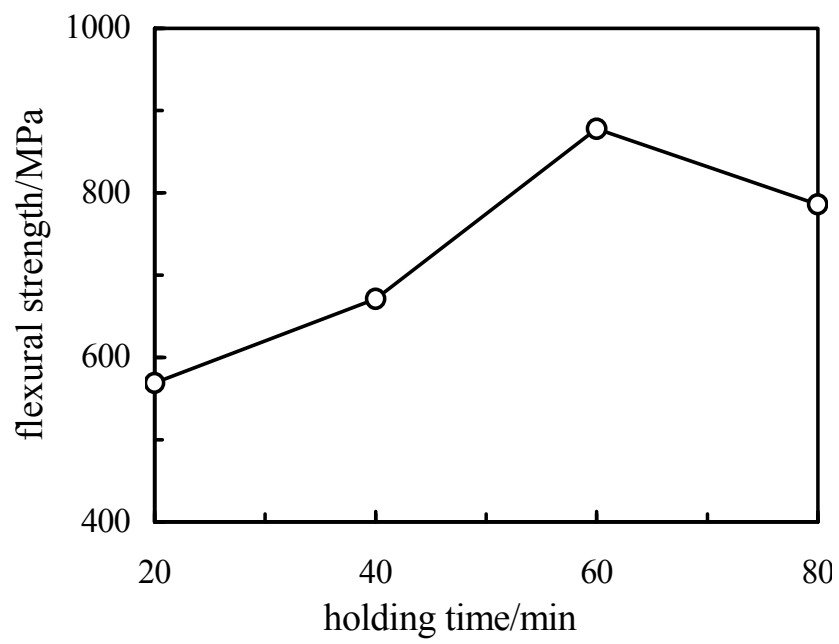

Fig. 6. Effects of holding time on the flexural strength

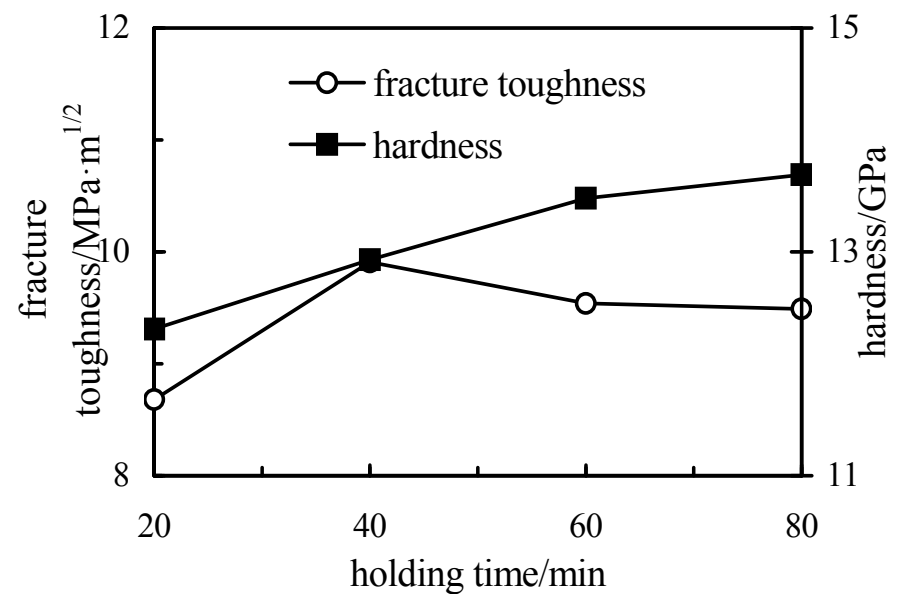

Fig. 7. Effects of holding time on the fracture toughness and hardness 


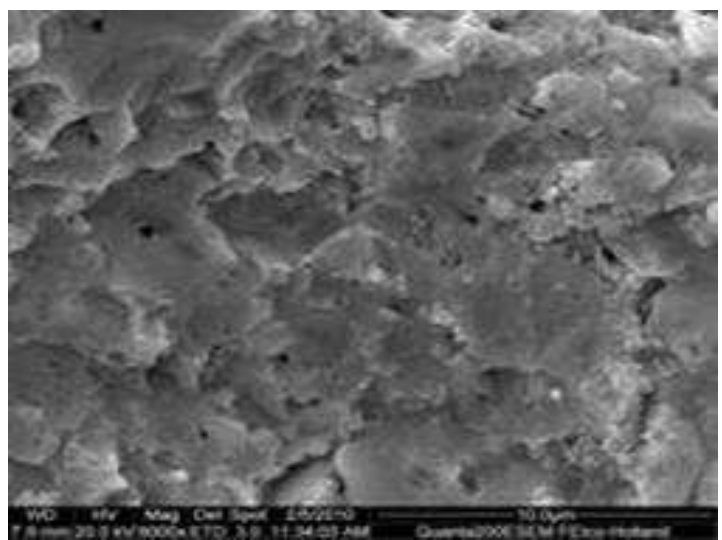

(a) remain $20 \mathrm{~min}$ at $1450{ }^{\circ} \mathrm{C}$

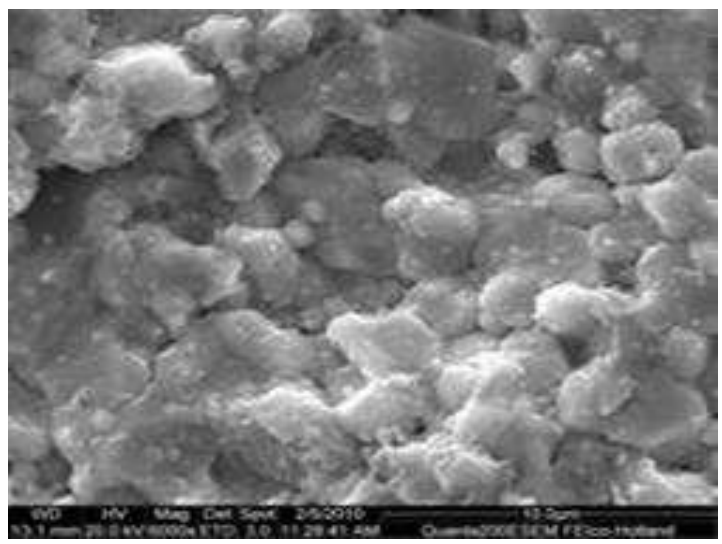

(b) remain $60 \mathrm{~min}$ at $1450{ }^{\circ} \mathrm{C}$

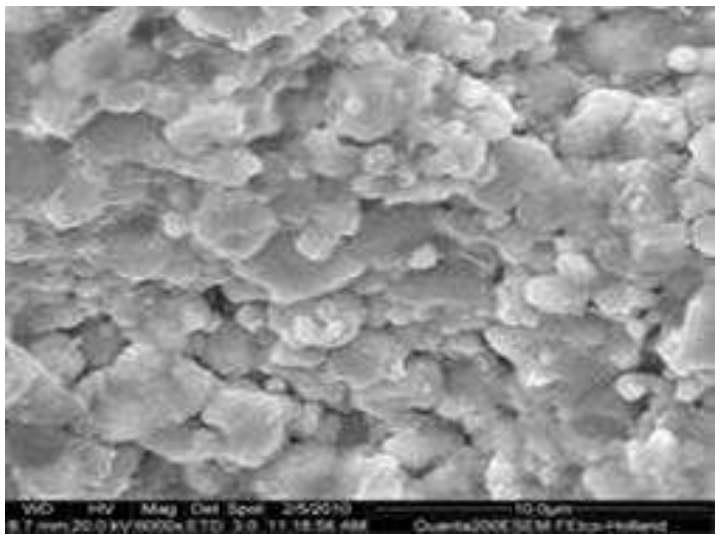

(c) remain $80 \mathrm{~min}$ at $1450{ }^{\circ} \mathrm{C}$

Fig. 8. SEM morphologies of the ceramic tool and die material under different holding times 


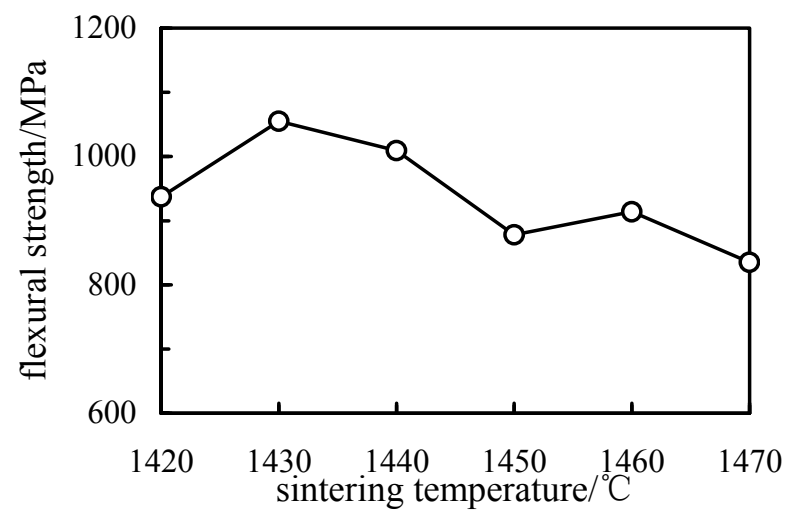

Fig. 9. Effects of hot pressing temperature on the flexural strength

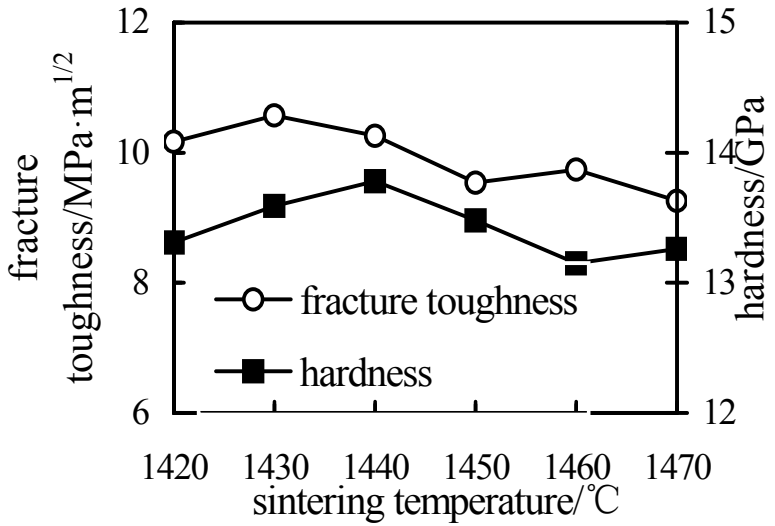

Fig. 10. Effects of hot pressing temperature on the fracture toughness and hardness

Fig. 11 shows the SEM morphologies of the $\mathrm{ZrO}_{2}$ nano-composite ceramic tool and die material sintered at the temperature of $1420^{\circ} \mathrm{C}, 1430{ }^{\circ} \mathrm{C}$ and $1450{ }^{\circ} \mathrm{C}$, with the holding time of $60 \mathrm{~min}$. It can be seen from Fig. 11 that the microstructure of the tested $\mathrm{ZrO}_{2}$ nanocomposite ceramic tool and die material is a typical kind of the intragranular/intergranular microstructure and the fracture mode is the mixture of both transgranular/intergranular fracture, and the mixture of both transgranular/ intergranular fracture occurred at $1430{ }^{\circ} \mathrm{C}$ is better than that which was sintered at $1420{ }^{\circ} \mathrm{C}$, this is the main reason for the high mechanical properties. Compared to the Fig.11(c), the microstructure of the composite materials at $1420^{\circ} \mathrm{C}$ and $1430{ }^{\circ} \mathrm{C}$ are obviously finer than that which was sintered at $1450{ }^{\circ} \mathrm{C}$. The abnormal grains which can be found in Fig.11 (c) could affect the mechanical properties of the composite material.

Therefore the appropriate sintering temperature of $\mathrm{ZrO}_{2}$ nanocomposite ceramic tool and die material is $1430^{\circ} \mathrm{C}$. 


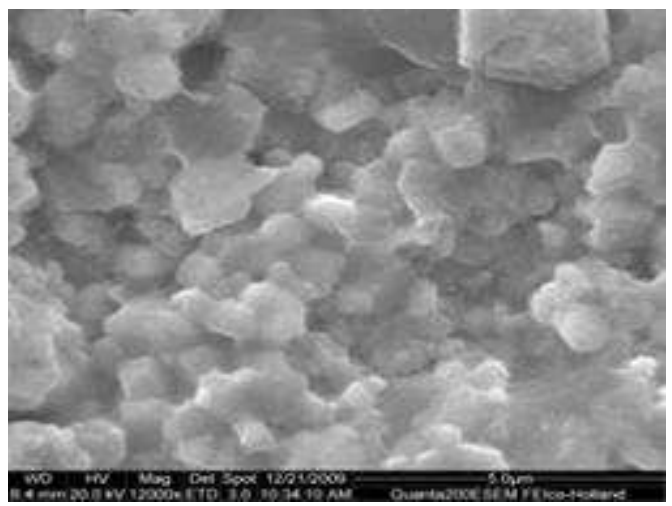

(a) $1420^{\circ} \mathrm{C}$

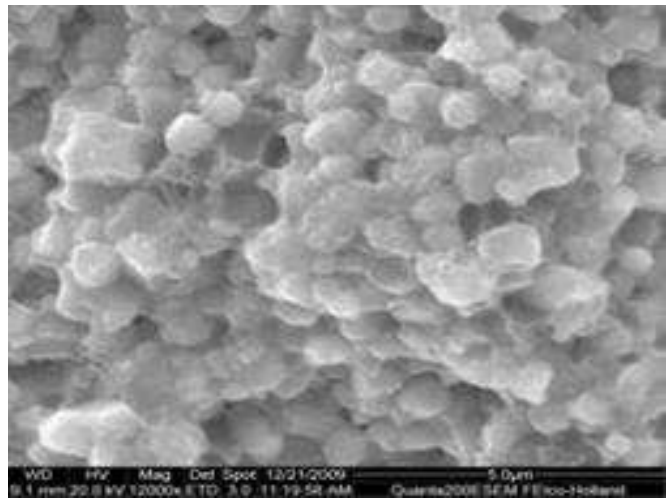

(b) $1430^{\circ} \mathrm{C}$

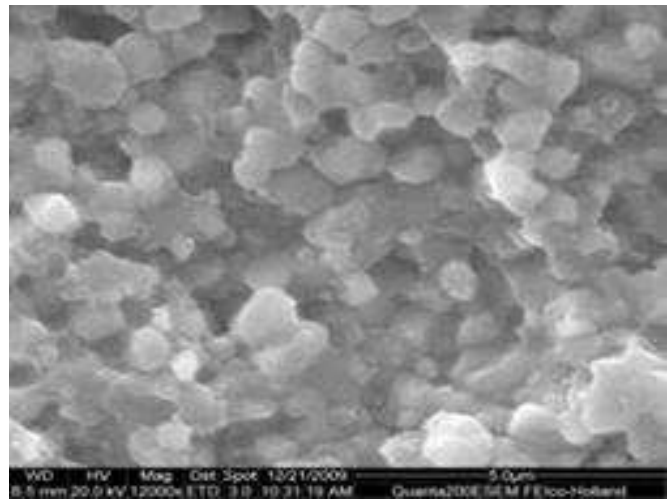

(c) $1450{ }^{\circ} \mathrm{C}$

Fig. 11. SEM morphologies of the ceramic tool and die material under different hot pressing temperatures 


\subsection{Sintering process of ceramic material}

Two kinds of ceramic materials were prepared by hot press technology at $1430{ }^{\circ} \mathrm{C}$ in vacuum with the time duration of $60 \mathrm{~min}$ and hot pressing pressure of $35 \mathrm{MPa}$. Besides, a time duration of $120 \mathrm{~min}$ at $1100{ }^{\circ} \mathrm{C}$ was added in composite 2 . The mechanical properties of the composites are shown in Table 3.

\begin{tabular}{|c|c|c|c|}
\hline Material & $\begin{array}{c}\text { Flexural strength } \\
/ \mathrm{MPa}\end{array}$ & $\begin{array}{c}\text { Fracture toughness } \\
/ \mathrm{MPa} \cdot \mathrm{m}^{1 / 2}\end{array}$ & $\begin{array}{c}\text { Hardness } \\
/ \mathrm{GPa}\end{array}$ \\
\hline Composite 1 & 765 & 8.18 & 11.6 \\
\hline Composite 2 & 878 & 9.54 & 13.48 \\
\hline
\end{tabular}

Table 3. Compositions and mechanical properties of the ceramic tool and die materials

It indicates that $1100{ }^{\circ} \mathrm{C}$ is approach the transformation temperature when the crystal structure of zirconium dioxide is transformed from monoclinic to tetragonal. This process also follows about $7 \%$ volume contraction. The nano-meter sized grains grow up generally after $1200{ }^{\circ} \mathrm{C}$. Keeping on hot pressing a period of time at this temperature firstly can make the crystal structure of zirconium dioxide be transformed from monoclinic to tetragonal; The second, it also can accelerate the sintering densification when the grain growth is not obvious which is benefit to obtain a more ideal microstructure and mechanical property of the nano-composite ceramic material.

As shown in Table 3, composite 2 has the same components and sintering process with composite 1 except this $120 \mathrm{~min}$ is sintering at $1100{ }^{\circ} \mathrm{C}$, but all the mechanical properties are noticeably higher than that of composite 1.

Investigation on the Vickers indentation is one of the effective methods to characterize the change of hardness and toughness. Fig. 12 shows the morphologies of Vickers indentation of both composite 1 and 2. As shown in Fig. 12 (a) and (b), the Vickers indentation of composite 2 is smaller than that of the composite 1 and the cracks of composite 1 are obviously. It indicates that this sinter process can enhance the hardness of $\mathrm{ZrO}_{2}$ ceramic materials. As shown in Fig. 12 (c) and (d), the crack of composite 2 is shorter and thinner than that of composite 1 , which suggests that the fracture toughness of composite 2 is higher than that of composite 1 obviously.

As shown in Fig. 12 (c) and (d), although the mechanical property of two materials has changed, the grain size and the distribution of $\mathrm{Al}_{2} \mathrm{O}_{3}$ and $\mathrm{TiB}_{2}$ are similar. It indicates that the enhancement of mechanical properties is mainly because the addition of $\mathrm{ZrO}_{2}$ and its phase transformation. These results suggest that keeping sintering of $120 \mathrm{~min}$ at $1100{ }^{\circ} \mathrm{C}$ can make all of the $\mathrm{ZrO}_{2}$ phase be transformed from monoclinic to tetragonal. It is a volume expansion process when the $\mathrm{ZrO}_{2}$ grains transforms from tetragonal symmetry to monoclinic symmetry. It is very difficult to make the tetragonal be transformed to monoclinic resulted from the high hot pressing pressure. Thus, most of the tetragonal $\mathrm{ZrO}_{2}$ grains can be kept after finish sintering until the room temperature.

When a crack appears and extends through the $\mathrm{ZrO}_{2}$ grains, the tetragonal grains will be transformed to monoclinic under the stress of crack tip. On the one hand, this process can absorb the fracture energy and reduce crack tip stress; on the other hand, phase 
transformation often follows by the volume expansion which can press the crack tip and cause the crack thinning or even stop extending. This process is the typical stress-induced transformation toughening.

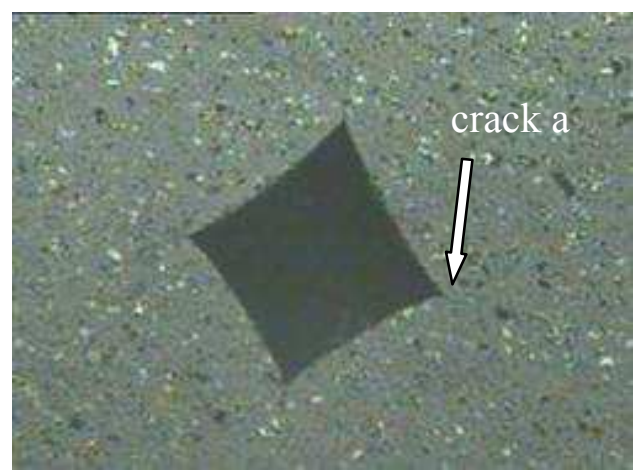

(a) composite $2(200 \times)$

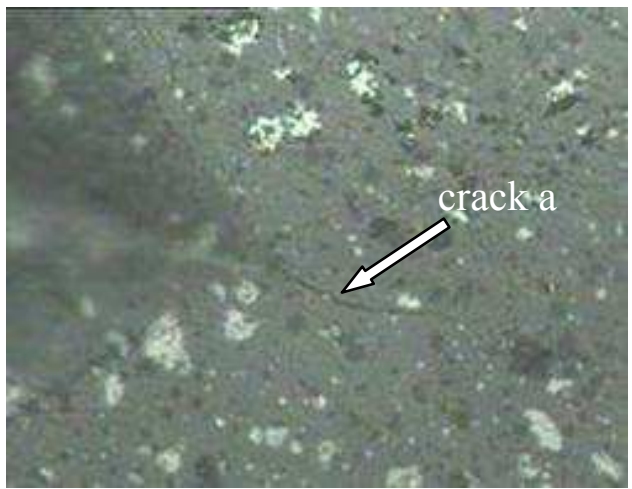

(c) composite $2(400 \times)$

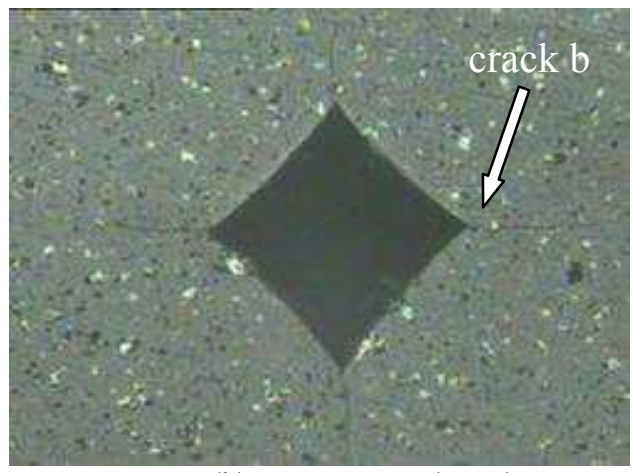

(b) composite $1(200 \times)$

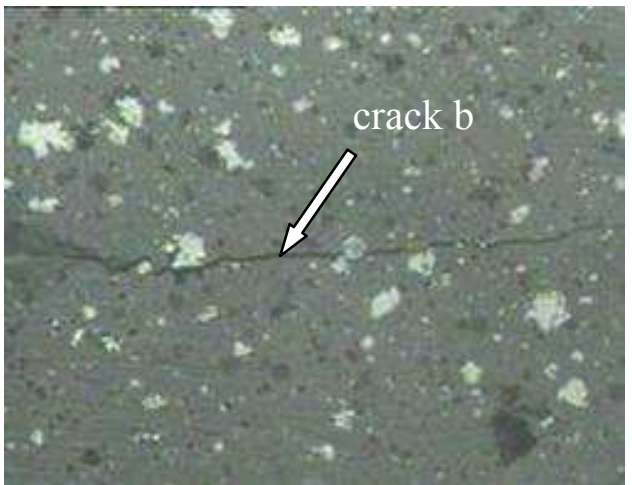

(d) composite $1(400 \times)$

Fig. 12. Morphologies of Vickers indentation

In order to study the change of phase transformation, the material surface is analyzed by XRD. As shown in Fig. 13(a) and (b), two diffraction peaks appears in nearby $30^{\circ}$ after the common sintering process, which is the monoclinic $\mathrm{ZrO}_{2}$. After the optimal sintering process, the monoclinic $\mathrm{ZrO}_{2}$ disappeared, and all of the $\mathrm{ZrO}_{2}$ grains are tetragonal symmetry.

Microstructure of both composite 1 and 2 materials under SEM are shown in Fig. 14. It can be seen that grains in composite 2 are finer than that in composite 1 . Most of the composite 1 material grains are about $200 \mathrm{~nm}$ while the composite 1 material only has few of fine grains distributed in the grain boundary. The finer the grain is, the higher the mechanical property of nano-meter composite ceramic material is. After 120 min sintering at $1100{ }^{\circ} \mathrm{C}$, materials have reached nearly the fall densification which can limit the grain growth space. 


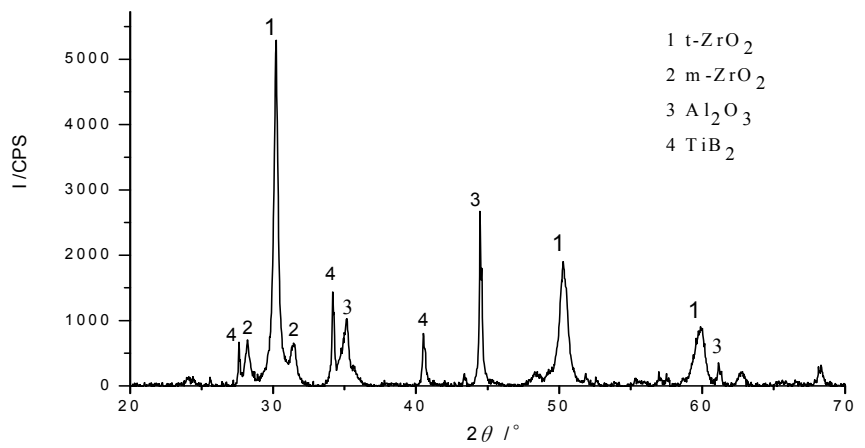

(a) mixed powder

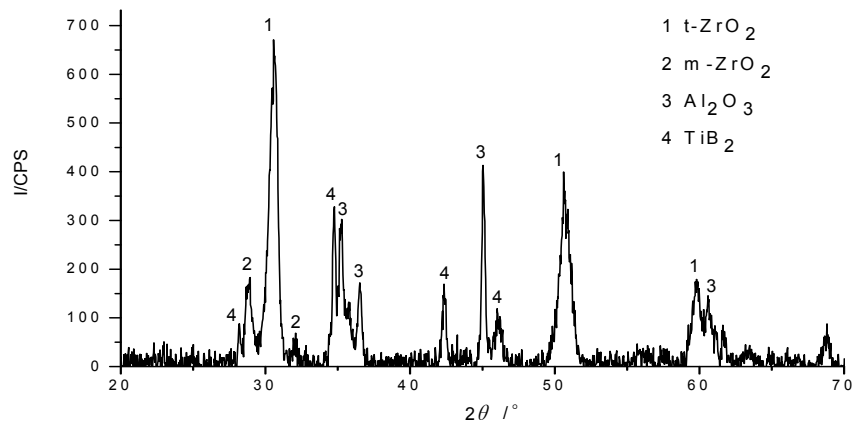

(b) common sintering process

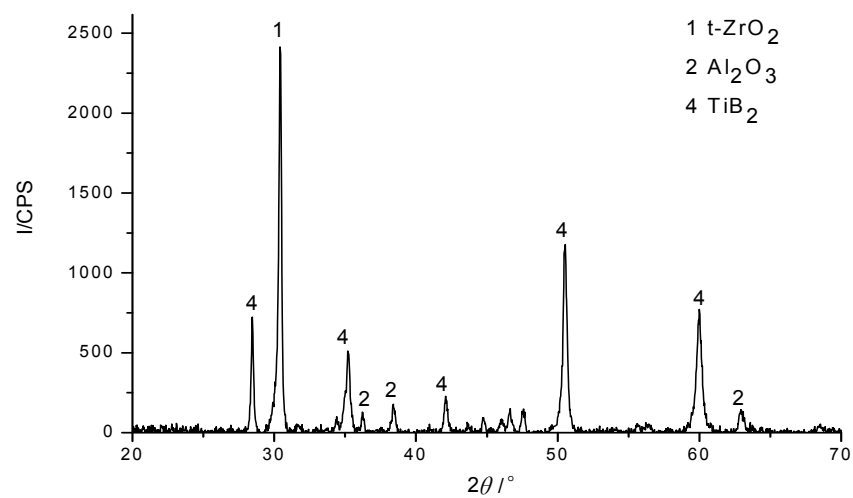

(c) optimal sintering process

Fig. 13. XRD analysis of nano-composite ceramic tool and die material 


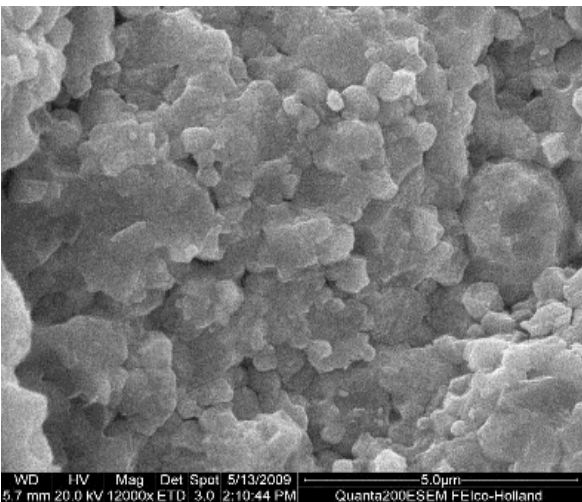

(a) composite1

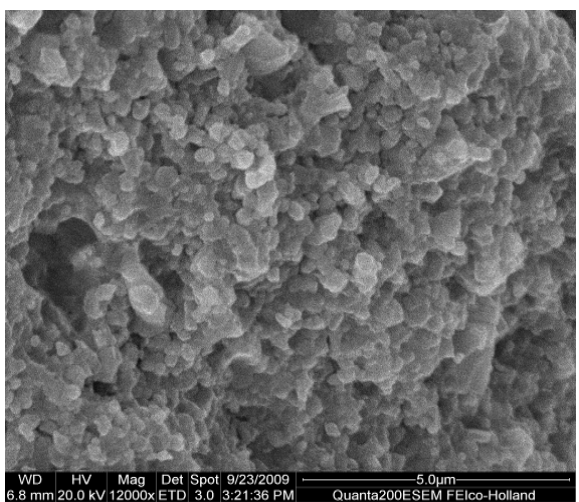

(b) composite 2

Fig. 14. SEM morphology of the composites with different sinter process

\section{Tribological design of $\mathrm{ZrO}_{2}$ nano-composite ceramic tool and die material}

In this experiment, the mechanical properties of $\mathrm{ZrO}_{2}$ nano-composites can be seen from Table 4.

\begin{tabular}{|c|c|c|c|c|c|}
\hline Material & $\begin{array}{c}\mathrm{TiB}_{2} \\
/ \mathrm{Vol} . \%\end{array}$ & $\begin{array}{c}\mathrm{Al}_{2} \mathrm{O}_{3} \\
/ \mathrm{Vol} . \%\end{array}$ & $\begin{array}{c}\text { Fracture toughness } \\
/ \mathrm{MPa} \cdot \mathrm{m}^{1 / 2}\end{array}$ & $\begin{array}{c}\text { Hardness } \\
/ \mathrm{GPa}\end{array}$ & $\begin{array}{c}\text { Flexural } \\
\text { strength } \\
/ \mathrm{MPa}\end{array}$ \\
\hline $\mathrm{a}$ & 5 & 10 & 10.59 & 10.20 & 501 \\
\hline $\mathrm{b}$ & 10 & 5 & 10.51 & 10.37 & 617 \\
\hline $\mathrm{c}$ & 10 & 10 & 11.37 & 10.71 & 612 \\
\hline $\mathrm{d}$ & 10 & 15 & 12.20 & 10.19 & 565 \\
\hline $\mathrm{e}$ & 15 & 10 & 7.91 & 10.22 & 524 \\
\hline
\end{tabular}

Table 4. Compositions and Mechanical properties of $\mathrm{ZrO}_{2}$ nano-composites

Fig.15 shows the friction coefficient and the wear rate of different $\mathrm{TiB}_{2}$ contents under the $200 \mathrm{r} / \mathrm{min}$ rotational speed and the load of $160 \mathrm{~N}$. The result shows that the friction coefficient of the composites decreases with the increase of $\mathrm{TiB}_{2}$ content, reaches the minimum when $\mathrm{TiB}_{2}$ content amounts to be 15 vol. \%. The wear rate of the composites decreases first and then increases with the increase of $\mathrm{TiB}_{2}$ content, reaches the minimum of $1.29 \times 10^{-6} \mathrm{~mm}^{3} / \mathrm{N} \cdot \mathrm{m}$ when $\mathrm{TiB}_{2}$ content amounts to be $10 \mathrm{vol} . \%$.

Contrast Fig.15 with Table 4, the changing trends of the friction and wear properties and the mechanical properties of the composites are roughly the same. The results indicated that the proper additive of $\mathrm{TiB}_{2}$ could improve both the friction and wear properties and the mechanical properties. Different $\mathrm{TiB}_{2}$ contents will significantly affect density of the material, and then the density directly affects the mechanical properties of materials. Although the additive of $\mathrm{TiB}_{2}$ could improve the friction and wear properties, the high $\mathrm{TiB}_{2}$ content also affect the microstructure of materials and the surface of materials was easy to be broken, and is bad for the friction and wear properties. 


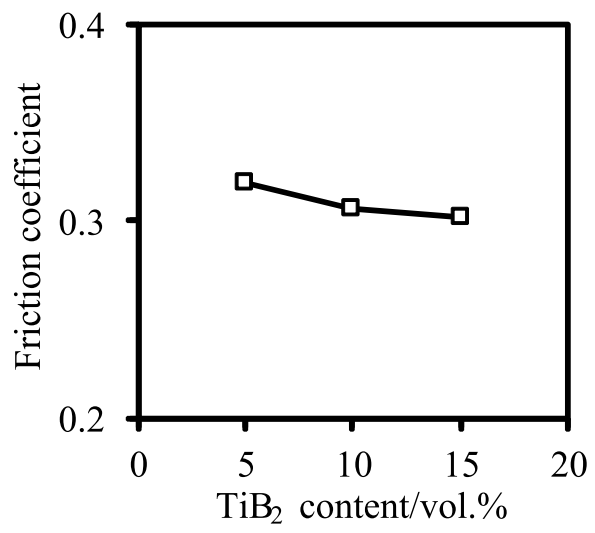

(a) friction coefficien

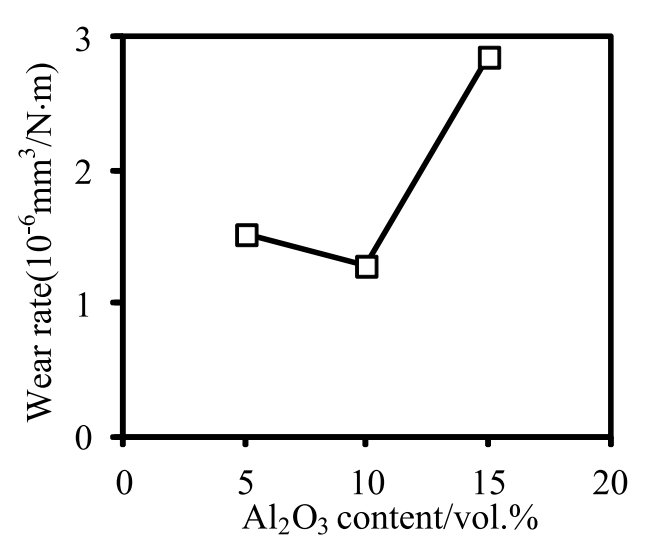

(b) wear rate

Fig. 15. Effect of different $\mathrm{TiB}_{2}$ contents on friction coefficient and wear rate

Fig.16 shows the friction coefficient and the wear rate of different $\mathrm{Al}_{2} \mathrm{O}_{3}$ contents under the $200 \mathrm{r} / \mathrm{min}$ rotational speed and the load of $160 \mathrm{~N}$. The result shows that the friction coefficient of the composites decreases first and then increases with the increase of $\mathrm{Al}_{2} \mathrm{O}_{3}$ content, reaches the minimum when $\mathrm{Al}_{2} \mathrm{O}_{3}$ content amounts to be 10 vol. \%. As the content of $\mathrm{Al}_{2} \mathrm{O}_{3}$ increases, the change of the wear rate is nearly the same in trend as that of the friction coefficient but not obvious, reaching the minimum of $1.286 \times 10^{-6} \mathrm{~mm}^{3} / \mathrm{N} \cdot \mathrm{m}$ when $\mathrm{Al}_{2} \mathrm{O}_{3}$ content amounts to be 10 vol. $\% . \mathrm{Al}_{2} \mathrm{O}_{3}$ is proved a strengthening material of $\mathrm{ZrO}_{2}$, the microstructure and the density of materials were obtained by the addition of $\mathrm{Al}_{2} \mathrm{O}_{3}$ particles, thus the mechanical properties of materials are increased, and reaches the maximum when $\mathrm{Al}_{2} \mathrm{O}_{3}$ content amounts to be 10 vol. \% (Table 4), and with increasing $\mathrm{Al}_{2} \mathrm{O}_{3}$ content (from 5 vol. \% to 10 vol. \% in composites), the friction and wear properties of $\mathrm{ZrO}_{2}$ composites are continuely increased, but increasing $\mathrm{Al}_{2} \mathrm{O}_{3}$ content further (up to 10 vol. \%), it is decreased.

The effect of material content on the friction and wear properties of the composites is obviously, proper material content not only increase the mechanical properties, but also improve the friction and wear behaviors. Compared with friction coefficient, the changing trends of wear rate with mechanical properties is obviously, the reason is that both of the good wear rate and well mechanical properties needed the finer microstructure, and the friction coefficient are mainly dependent on the $\mathrm{TiB}_{2}$ content [Mazaheri et al, 2008].

Fig.17 shows that the surface of the composite is smooth and a small amount of defect area can also be observed. The smooth surface is mainly because of the friction between the ceramic material and the steel ring. The friction chip has high surface activity and easy adheres to the material surface, forming the continual surface layer on the surface with the increase of wear time. The smooth and continue surface layer can effectively reduce the coefficient and slow the wear. With the temperature of friction area increase, wear increase because of the plastic deformation and material transfer take place, form the adhesive wear. 


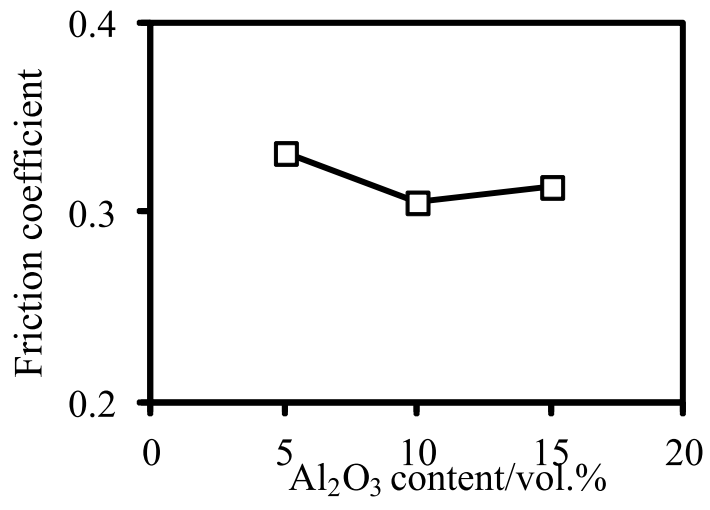

(a) Friction coefficient

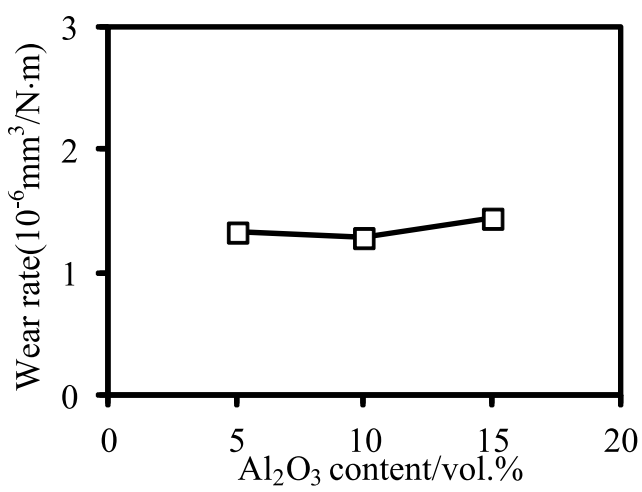

(b) Wear rate

Fig. 16. Effects of different $\mathrm{TiB}_{2}$ content on friction coefficient and wear rate

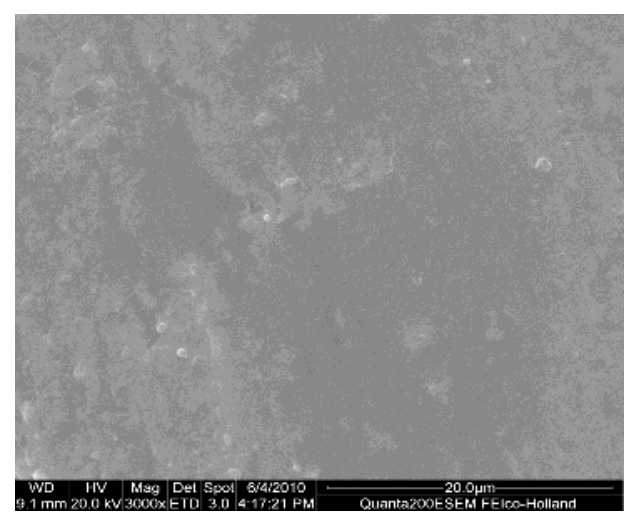

(a) $3000 \times$

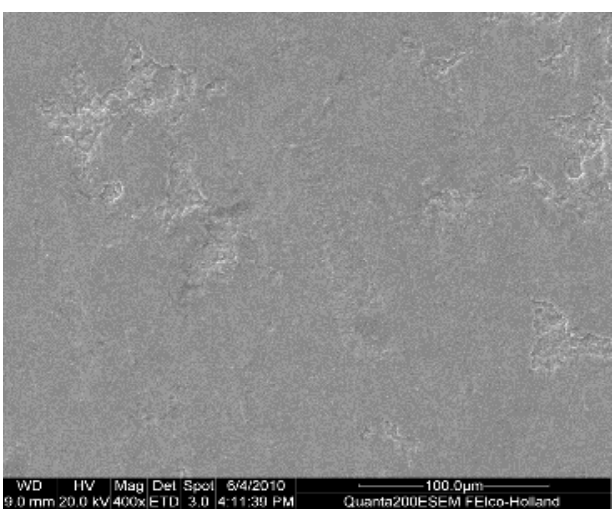

(b) $400 \times$

Fig. 17. SEM morphologies of $\mathrm{ZrO}_{2}$ nano-composite ceramic tool and die material 
XRD was used to analyze the physics of surface film(Fig.18). More $\mathrm{TiB}_{2}$ and $\mathrm{Al}_{2} \mathrm{O}_{3}$ can be seen from Fig.18(b), the main reason is that the hardness of $\mathrm{TiB}_{2}$ and $\mathrm{Al}_{2} \mathrm{O}_{3}$ is higher than $\mathrm{ZrO}_{2}$ and this can reduce the wear in friction. Secondly, $\mathrm{TiB}_{2}$ is proved a self-lubricating material which can low friction coefficient. Besides, $\mathrm{FeO}$ was found on the material surface after the test (Fig.18(b)), this was come from the reaction between the steel chip and the atmosphere under the friction heat and moved by friction. The softer $\mathrm{FeO}$ chips and the ceramic chips were mixed by the mechanical pressure, formed the surface layer which can protect the ceramic material and reduced the wear.

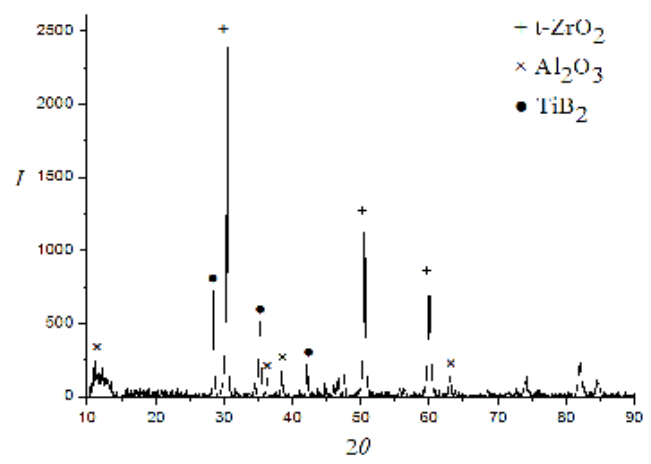

(a)before the test

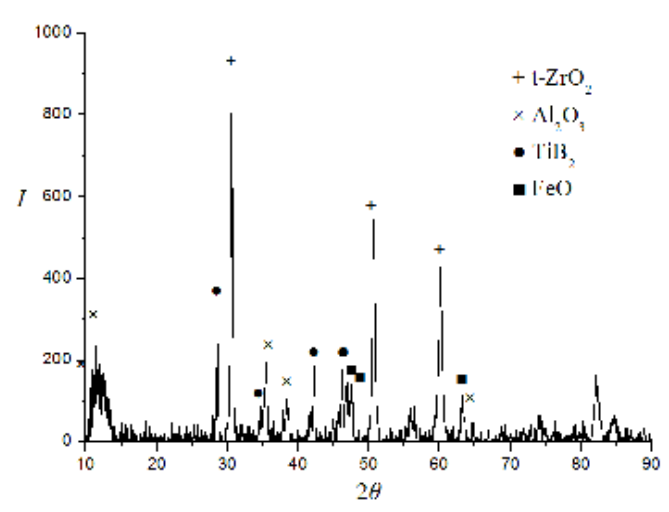

(b) after the test

Fig. 18. XRD analysis of $\mathrm{ZrO}_{2}$ nano-composite ceramic tool and die material

\section{Friction and wear behaviour}

Fig.19 shows the effects of load and rotational speed on the friction coefficient of composites. The friction coefficient of the composites first and then decreases with the increases of load under the $200 \mathrm{r} / \mathrm{min}$ rotational speed, and the friction coefficient of the composites decreases with the increases of rotational speed under the $160 \mathrm{~N}$ load. The friction coefficient reaches the minimum of 0.3 and 0.29 when the load is $240 \mathrm{~N}$ and the rotational speed is $200 \mathrm{r} / \mathrm{min}$, respectively. 


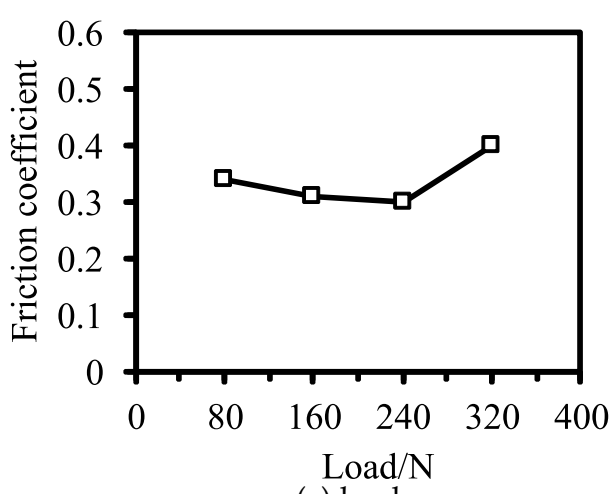

(a) load

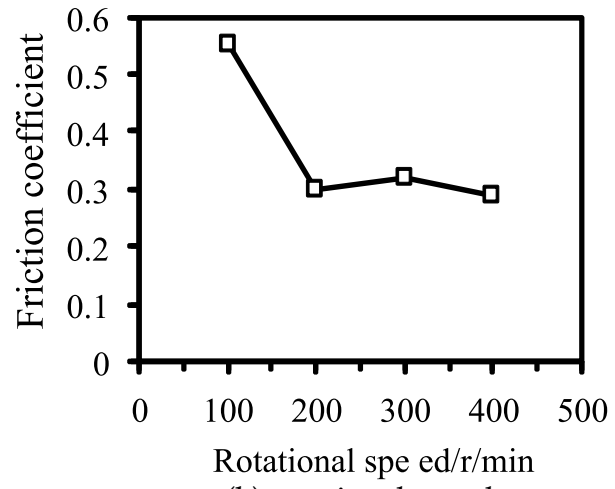

(b) rotational speed

Fig. 19. Effects of load and rotational speed on the friction coefficient

Fig.20 shows the effects of load and rotational speed on the wear rate of composites. The change of wear rate is near the same with the friction coefficient. The wear rate decreases with the load from $80 \mathrm{~N}$ to $240 \mathrm{~N}$ under the $200 \mathrm{r} / \mathrm{min}$ rotational speed, but when the load increase to $320 \mathrm{~N}$, the wear rate reach the maximum, $5.44 \times 10^{-6} \mathrm{~mm}^{3} / \mathrm{N} \cdot \mathrm{m}$. The wear rate decreases with the speed increase as can be seen in Fig.20(b).

Fig.21 shows the SEM of the wear surface with $160 \mathrm{~N}$ and $200 \mathrm{r} / \mathrm{min}$. The surface is smooth and most of the surface is covered by a nearly continuous layer in Fig. 21(a). The wear appearance of ceramic surface mainly includes two parts, part 1 is a smooth and grey area (point 1 in Fig.21), part 2 is the saddle(point 2 in Fig.21). In order to attribute the phase differences of the two parts, the EDAX electron spectrum analysis was carried out. Fig.21 (a) and (b) shows the electron spectrum analytic curve of point 1 and point 2 .

As can be seen from Fig. 22, main elements come from the composite ceramic material. A few Fe exist obviously in point 1 , but no Fe element can be found in point 2 . Fe comes from the $45 \#$ steel work-piece. The chips which produced in the friction process has the high activeness, easily adheres in the friction surface and some shifted to the ceramic surface along with the friction process. After the progression rolling, the mix chips forms a soft and continuous film on the ceramic surface.

XRD was used to analyze the phase change in the friction. Fig.23 shows the XRD of the material surface before and after the wear test. FeO can be found on the ceramic surface after the friction(in Fig. 23(b)), and it came from the reaction between Fe and oxygen of air. The results indicated that the layer united by the work piece materials and ceramic materials. In addition, more $\mathrm{TiB}_{2}$ were found on the ceramic surface. $\mathrm{TiB}_{2}$ is a self-lubricating material and harder than the matrix material. Along with the friction, the $\mathrm{TiB}_{2}$ content was become more and slow down the wear aggravation.

Defects also can be found from the film (point 3 in Fig. 21(b)). The colour of defects is similar to the film but obviously different from the original material. Moreover, defect is smaller and shallower than the original material. The results indicated that the material composition of the defect and film is roughly the same. Zirconium dioxide is ionic crystal, the adsorption affinity to the chip is higher. The ceramic chips mixed with workpiece chips and form the continuous film, the defect is the damage of the mixed film. 


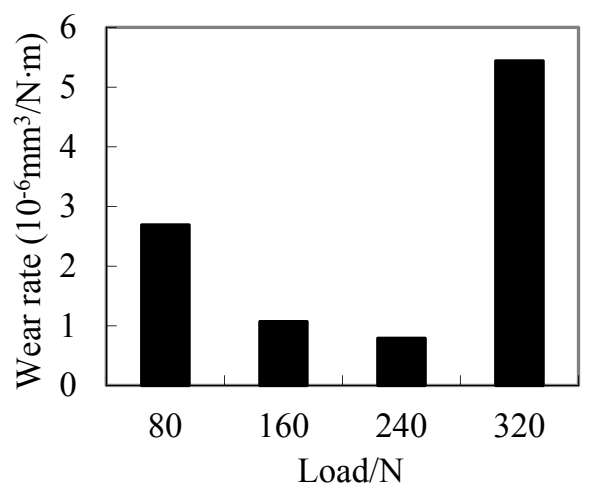

(a) load

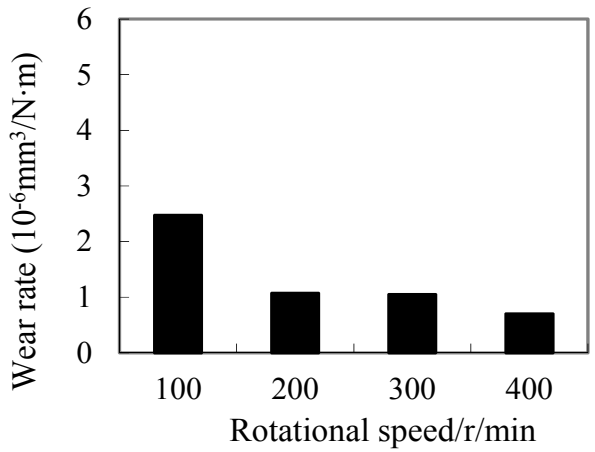

(b) rotational speed

Fig. 20. Effects of load and rotational speed on the wear rate

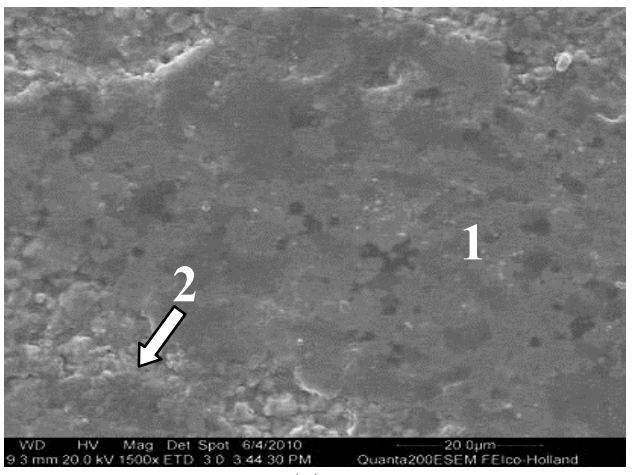

(a)

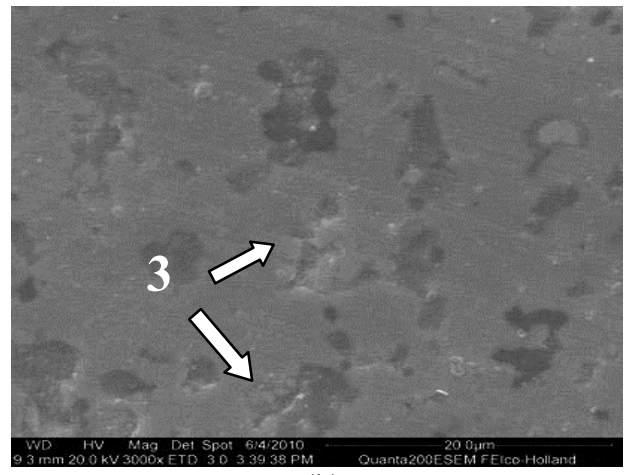

(b)

Fig. 21. SEM morphologies of the wear surface with the load of $160 \mathrm{~N}$ and speed of $200 \mathrm{r} / \mathrm{min}$ 


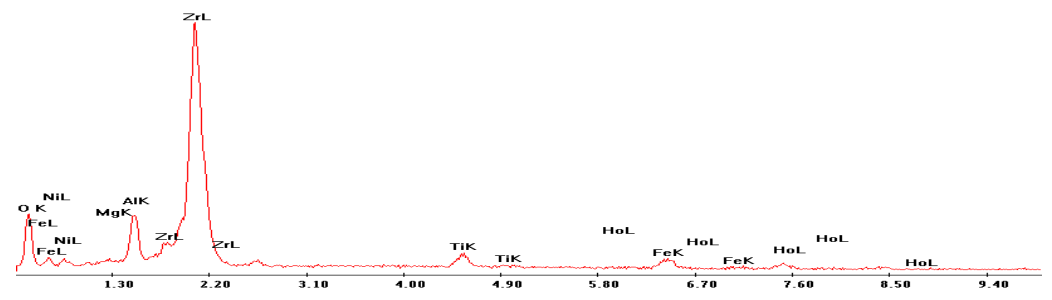

(a) point 1

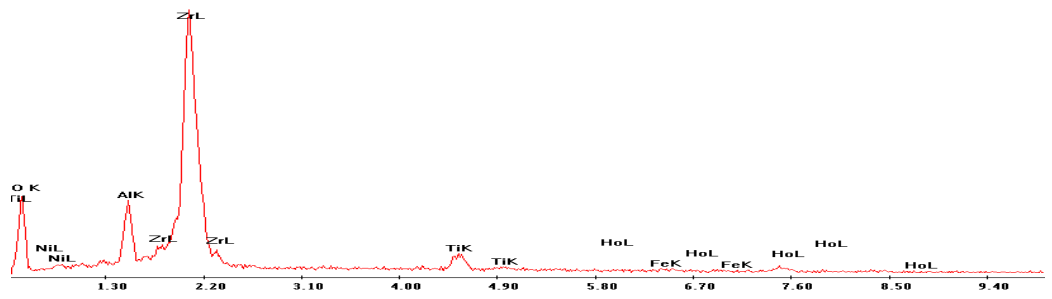

(b) point 2

Fig. 22. EDAX electron spectrum of the wear surface

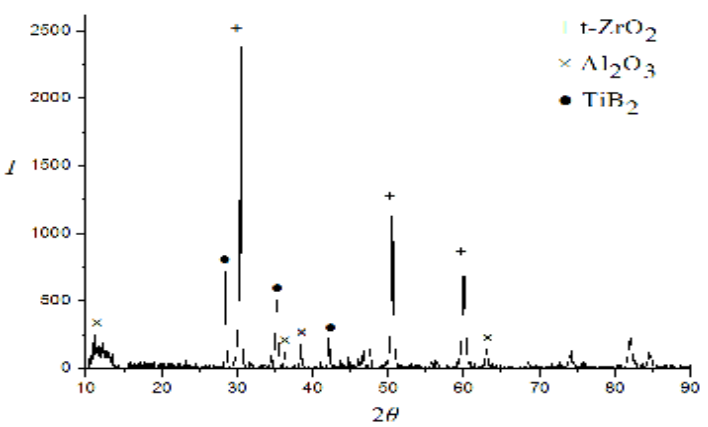

(a) before the wear test

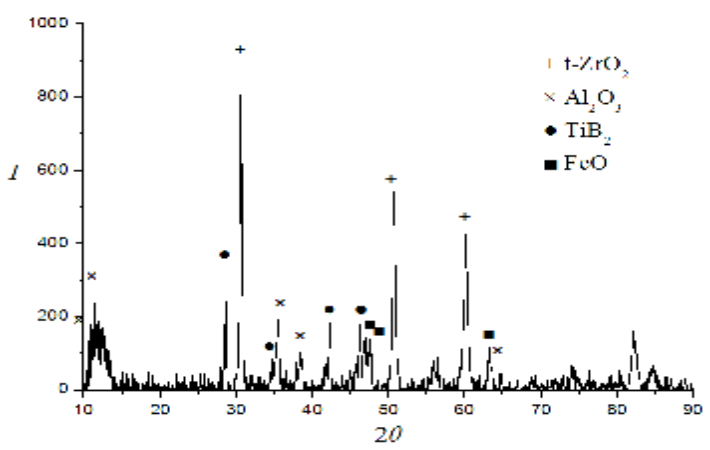

(b) after the wear test

Fig. 23. XRD analysis of nano-composite ceramic tool and die material surface 
The result shows that the soft layer was produced in the stage of adhesive wear process, the soft work-piece material chips were mixed the ceramic chips and coated on the hard composite ceramic surface under the friction. Next, the friction mainly between the soft layer and work-piece, this is the main reason of the low friction coefficient and wear rate. First, the soft layer form a continual smooth rubbing surface on the composite materials surface, and increases the actual friction contacted area, reduces the friction moment; Second, the soft layer reduce the direct contact between the work-piece and ceramic, thus slowed down the wear of composite ceramic.

Fig.24 shows the SEM morphology of the wear section of the composite when the rotational speed is $200 \mathrm{r} / \mathrm{min}$ and the normal load is $160 \mathrm{~N}$ and $320 \mathrm{~N}$, respectively.

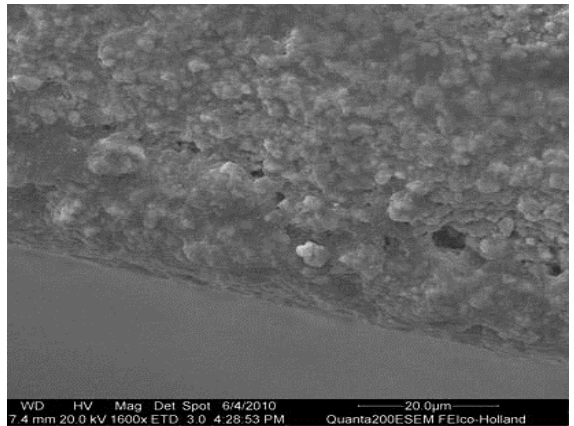

(a) $160 \mathrm{~N}$

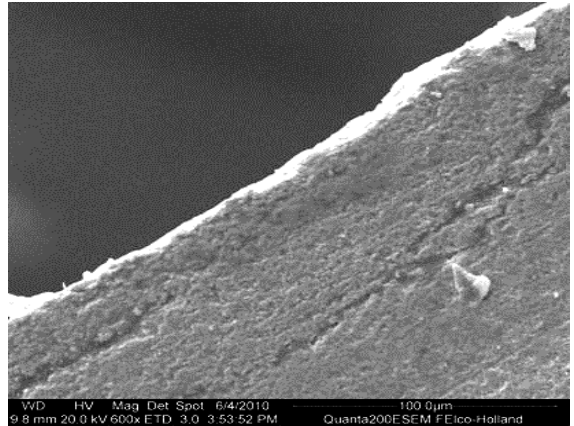

(b) $320 \mathrm{~N}$

Fig. 24. SEM of the wear section with 200r/min and different load

As shown in Fig. 24(a) and (b), when the rotational speed is $200 \mathrm{r} / \mathrm{min}$ and the normal load is $160 \mathrm{~N}$, the wear of composite ceramic is light, there is only a few flaw in the wearing course and mainly distributes in about 10 microns wear courses. The flaw is exist independently and without jointed, so it is not easy to form the serious wear as seen in Fig. 24(b).

As shown in Fig. 24(b), some transverse cracks were found in the wear layer when the load increases to $320 \mathrm{~N}$. The cracks could cause the wear layer broken and finally form the spalling wear. When the load is low, the wear layer does not have the obvious change, wear is mainly by the slight scuffing of ceramic, and because of the hardness of ceramic is far high than the work-piece, the wear rate is low. When the load is $320 \mathrm{~N}$, the wear layer is easy broken and can't effectively protect the matrix material, wear rate is higher than that in low load. The test result of wear rate can be seen from Fig.20. When the load is $160 \mathrm{~N}$ the wear rate is $1.06 \times 10^{-6} \mathrm{~mm}^{3} / \mathrm{Nm}$. While when the load is $320 \mathrm{~N}$ the rate of wear increases rapidly to be $5.44 \times 10^{-6} \mathrm{~mm}^{3} / \mathrm{Nm}$.

\section{Conclusion}

A new $\mathrm{ZrO}_{2}$ nano-composite ceramic tool and die material was prepared by vacuum hot pressing technique. $\mathrm{ZrO}_{2}-\mathrm{TiB}_{2}-\mathrm{Al}_{2} \mathrm{O}_{3}$ nano-composite ceramic tool and die material with 10 vol. $\% \mathrm{TiB}_{2}$ and 10 vol. $\% \mathrm{Al}_{2} \mathrm{O}_{3}$ micrometer sized powders reaches the maximum mechanical property. $\mathrm{ZrO}_{2}-\mathrm{TiB}_{2}-\mathrm{Al}_{2} \mathrm{O}_{3}$ nano-composite ceramic tool and die material with optimum mechanical properties can be achieved when the hot pressing temperature is 
$1430^{\circ} \mathrm{C}$, and the holding time is $60 \mathrm{~min}$. The flexural strength, hardness and fracture toughness reaches $1055 \mathrm{MPa}, 13.59 \mathrm{GPa}$ and $10.57 \mathrm{MPa} \mathrm{m}^{1 / 2}$, respectively. In the $\mathrm{ZrO}_{2}$ nanocomposite ceramic tool and die materials, the optimum sinter parameters could improve the microstructure, and the optimum sinter process could nearly completely stabilize the $\mathrm{t}-\mathrm{ZrO}_{2}$ to the room temperature condition that can enhance the toughening effect of $\mathrm{ZrO}_{2}$. The additive of self-lubricating material $\mathrm{TiB}_{2}$ could reduce the friction coefficient and improve the abrasion resistance. Moreover, the $\mathrm{TiB}_{2}$ content was become more under the continuous friction condition which is able to slow down the wear aggravation. The continuous friction film was formed by the ceramic and work-piece chips under the friction. The film could reduce the friction and protect the matrix material. The wear rate of $\mathrm{ZrO}_{2}$ nano-composite ceramic tool and die material is $1.06 \times 10^{-6} \mathrm{~mm}^{3} / \mathrm{Nm}$ when the rotational speed is $200 \mathrm{r} / \mathrm{min}$ and the normal load is $160 \mathrm{~N}$. It indicated that this new ceramic composite have good friction and wear properties. Therefore, it can be expected that the developed $\mathrm{ZrO}_{2}$ nano-composite ceramic material will get further application in the field of cutting tools, dies and other wear resistant parts, etc. with high wear resistance and performance.

\section{Acknowledgement}

This work was supported by Shandong Provincial Natural Science Foundation, China (Grant No. ZR2009FZ005), the Program for New Century Excellent Talents in University of China (Grant No. NCET-10-0866), the National Natural Science foundation of China (Grant No. 51075248), Shandong Provincial Natural Science Foundation for Distinguished Young Scientists, China (Grant No. JQ201014).

\section{References}

Liu J. \& Zhou F. (2003). Properties and Applications of Ceramic Materials for Hot Extrusion Dies. Rare Metal Materials and Engineering, Vol. 32, No. 3, Mar, 2003, pp. 232-235, ISSN 1002-185X

Kar A.; Tobyn M. J. \& Ron S. (2004). An Application for Zirconia as a Pharmaceutical Die Set. Journal of the European Ceramic Society, Vol. 24, No. 10-11, Sep, 2004, pp. 30913101, ISSN 09552219

Basu B; Lee J \& Kim D. (2004). Development of Nanocrystalline Wear-resistant Y-TZP Ceramics. Journal of the American Ceramic Society, Vol. 87, No. 9, Sep, 2004, pp. 17711774, ISSN 00027820

Hirvonen A.; Nowak R. \& Yamamoto Y. (2006). Fabrication, Structure, Mechanical and Thermal Properties of Zirconia-based Ceramic Nanocomposites. Journal of the European Ceramic Society, Vol. 26, No. 8, May, pp. 1497-1505, ISSN 09552219

Guicciardi S.; Shimozono T.\& Pezzotti G. (2006). Nanoindentation Characterization of Submicrometric Y-TZP Ceramics. Advanced Engineering Materials, Vol. 8, No. 10, Oct, 2006, pp. 994-997, ISSN 14381656

Zhang Y. S.; Hu L. T.; Chen J. M. \& Liu W. M. (2009) . Fabrication of Complex-shaped YTZP $/ \mathrm{Al}_{2} \mathrm{O}_{3}$ Nanocomposites. Journal of Materials Processing Technology, Vol. 209, No. 3, Feb, 2009, pp. 1533-1537, ISSN 09240136

Liu H. W. \& Xue Q. J.(1996). The Tribological Properties of TZP-graphite Self-lubricating Ceramics. Wear, Vol. 198, No.1-2, Oct, 1996, pp.143-149, ISSN 00431648 
Yang C. T. \& Wei C. J.(2000). Effects of Material Properties and Testing Parameters on Wear Properties of Fne-grain Zirconia (TZP). Wear, Vol. 242, No. 1-2, Jul, 2000, pp.97-104, ISSN 00431648

Baharvandi H.; Hadian A. \& Alizadeh A.(2006). Processing and Mechanical Properties of Boron Carbide-titanium Diboride Ceramic Matrix Composites. Applied Composite Materials, Vol. 13, No. 3, May, 2006, pp. 191-198, ISSN 0929189X

Basu B.; Vleugels J. \& Biest O. (2005). Processing and Mechanical Properties of $\mathrm{ZrO}_{2}-\mathrm{TiB}_{2}$ Composites. Journal of the European Ceramic Society, Vol. 25 , No.16, May,2005, pp.3629- 3637, ISSN 09552219

Hirvonen A.; Nowak R. \& Yamamoto Y. (2006). Fabrication, Structure, Mechanical and Thermal Properties of Zirconia-based Ceramic Nanocomposites. Journal of the European Ceramic Society, Vol. 26, No. 8, May, 2006, pp. 1497-1505, ISSN 09552219

Gupta T. K.; Bechtold J. H. \& Kuznicki R. C.(1977). Stabilization of Tetragonal Phase in Polycrystalline Zirconia. Journal of Materials Science, Vol.12, No.12. Dec, 1977,pp.2421-2426, ISSN 00222461

Hannink R.; Kelly P. \& Muddle B.(2000). Transformation toughening in zirconia-containing ceramics. Journal of the American Ceramic Society. Vol.83, No. 3, Mar, 2000, pp. 461487. ISSN 00027820

$\mathrm{Tu}$ J.\& Li J. Effect of phase transformation induced plasticity on the erosion of TZP ceramics. Materials Letters, Vol. 31, No. 3-6, Jun, 1997, pp. 267-270 , ISSN 0167577X

Guicciardi S.; Shimozono T. \& Pezzotti G. (2006). Nanoindentation characterization of submicrometric Y-TZP ceramics. Advanced Engineering Materials, Vol. 8, No. 10, Oct, 2006, pp. 994-997, ISSN 14381656

Elshazly E.; Ali M. \& Hout S.(2008). Alumina effect on the phase transformation of 3Y-TZP ceramics. Journal of Materials Science and Technology, Vol. 24, No.6, Nov, 2008, pp. 873-877,ISSN 10050302

Mazaheri M.; Simchi A. \& Golestani F.(2008). Densification and grain growth of nanocrystalline 3Y-TZP during two-step sintering. Journal of the European Ceramic Society, Vol. 28, No. 15, Nov, 2008, pp. 2933-2939 , ISSN 09552219 


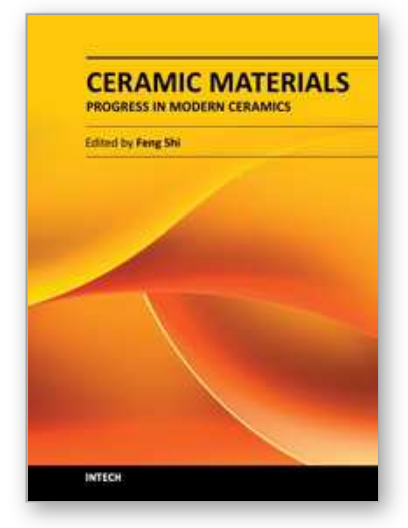

\author{
Ceramic Materials - Progress in Modern Ceramics \\ Edited by Prof. Feng Shi
}

ISBN 978-953-51-0476-6

Hard cover, 228 pages

Publisher InTech

Published online 05, April, 2012

Published in print edition April, 2012

This text covers ceramic materials from the fundamentals to industrial applications. This includes their impact on the modern technologies, including nano-ceramic, ceramic matrix composites, nanostructured ceramic membranes, porous ceramics, and the sintering theory model of modern ceramics.

\title{
How to reference
}

In order to correctly reference this scholarly work, feel free to copy and paste the following:

Chonghai Xu, Mingdong Yi, Jingjie Zhang, Bin Fang and Gaofeng Wei (2012). Development of Zirconia Nanocomposite Ceramic Tool and Die Material Based on Tribological Design, Ceramic Materials - Progress in Modern Ceramics, Prof. Feng Shi (Ed.), ISBN: 978-953-51-0476-6, InTech, Available from: http://www.intechopen.com/books/ceramic-materials-progress-in-modern-ceramics/development-of-zirconiananocomposite-ceramic-tool-and-die-material-based-on-tribological-design

\section{INTECH}

open science | open minds

\author{
InTech Europe \\ University Campus STeP Ri \\ Slavka Krautzeka 83/A \\ 51000 Rijeka, Croatia \\ Phone: +385 (51) 770447 \\ Fax: +385 (51) 686166 \\ www.intechopen.com
}

\author{
InTech China \\ Unit 405, Office Block, Hotel Equatorial Shanghai \\ No.65, Yan An Road (West), Shanghai, 200040, China \\ 中国上海市延安西路65号上海国际贵都大饭店办公楼 405 单元 \\ Phone: +86-21-62489820 \\ Fax: +86-21-62489821
}


(C) 2012 The Author(s). Licensee IntechOpen. This is an open access article distributed under the terms of the Creative Commons Attribution 3.0 License, which permits unrestricted use, distribution, and reproduction in any medium, provided the original work is properly cited. 